Article (refereed) - postprint

Toberman, Hannah; Tipping, Edward; Boyle, John F.; Helliwell, Rachel C.; Lilly, Allan; Henrys, Peter A. 2015. Dependence of ombrotrophic peat nitrogen on phosphorus and climate. Biogeochemistry, 125 (1). 11-20. 10.1007/s10533-015-0117-0

(C) Springer International Publishing Switzerland 2015

This version available http://nora.nerc.ac.uk/511402/

NERC has developed NORA to enable users to access research outputs wholly or partially funded by NERC. Copyright and other rights for material on this site are retained by the rights owners. Users should read the terms and conditions of use of this material at

http://nora.nerc.ac.uk/policies.html\#access

This document is the author's final manuscript version of the journal article, incorporating any revisions agreed during the peer review process. There may be differences between this and the publisher's version. You are advised to consult the publisher's version if you wish to cite from this article.

The final publication is available at Springer via http://dx.doi.org/10.1007/s10533-015-0117-0

Contact CEH NORA team at noraceh@ceh.ac.uk

The NERC and CEH trademarks and logos ('the Trademarks') are registered trademarks of NERC in the UK and other countries, and may not be used without the prior written consent of the Trademark owner. 


\section{Dependence of ombrotrophic peat nitrogen on phosphorus and climate}

4 Hannah Toberman ${ }^{1,2}$, Edward Tipping ${ }^{2}$, John F Boyle ${ }^{1}$, Rachel C Helliwell ${ }^{3}$, Allan Lilly ${ }^{3}$, Peter A Henrys ${ }^{2}$

5

$6 \quad{ }^{1}$ School of Environmental Sciences, University of Liverpool, Liverpool, L69 3GP

$7 \quad{ }^{2}$ Centre for Ecology and Hydrology, Lancaster Environment Centre, Lancaster, LA1 4AP

$8{ }^{3}$ The James Hutton Institute, Craigiebuckler, Aberdeen, AB15 8QH, Scotland, UK

9

10

Correspondence to: Professor Edward Tipping 
Nitrogen $(\mathrm{N})$ is a key, possibly limiting, nutrient in ombrotrophic peat ecosystems, and enrichment by pollutant $\mathrm{N}$ in atmospheric deposition $\left(\mathrm{N}_{\mathrm{dep}}, \mathrm{g} \mathrm{m}^{-2} \mathrm{a}^{-1}\right)$ is of concern with regard to peatland damage. We collated data on the $\mathrm{N}$ content of surface (depth $\leq 25 \mathrm{~cm}$, mean $15 \mathrm{~cm}$ ) ombrotrophic peat $\left(\mathrm{N}_{\mathrm{sp}}\right)$ for 215 sites in the UK and 62 other sites around the world, including boreal, temperate and tropical locations (wider global data), and found $\mathrm{N}_{\mathrm{sp}}$ to range from $0.5 \%$ to $4 \%$. We examined the dependences of $N_{s p}$ on surface peat phosphorus $(P)$ content $\left(P_{s p}\right)$, mean annual precipitation (MAP), mean annual temperature (MAT) and $\mathrm{N}_{\text {dep. }}$. Linear regression on individual independent variables showed highly significant $(p<0.001)$ correlations of $N_{s p}$ with $P_{s p}\left(r^{2}=0.23\right)$ and MAP $\left(r^{2}=\right.$ $0.14)$, and significant $(p<0.01)$ but weaker correlations with MAT $\left(r^{2}=0.03\right)$ and $N_{\text {dep }}\left(r^{2}=0.03\right)$. A multiple regression model using log-transformed values explained $36 \%$ of the variance of the UK data, $84 \%$ of the variance of the wider global data, and $47 \%$ of the variance of the combined data, all with high significance $(p<0.001)$. In all three cases, most of the variance was explained by $P_{s p}$ and MAP, but in view of a positive correlation between MAP and MAT for many of the sites, a role for MAT in controlling $\mathrm{N}_{\mathrm{sp}}$ cannot be ruled out. There is little evidence for an effect of $\mathrm{N}_{\text {dep }}$ on $\mathrm{N}_{\text {sp. }}$. The results point to a key role of $\mathrm{P}$ in $\mathrm{N}$ fixation, and thereby $\mathrm{C}$ fixation, in ombrotrophic peats.

Key words: 
The role of nitrogen $(\mathrm{N})$ in peatland ecosystem dynamics has received much recent attention, primarily due to concern about the effects of anthropogenically-driven elevated atmospheric $\mathrm{N}$ deposition ( $\mathrm{N}_{\text {dep }}$ ) on carbon sequestration (Turunen et al. 2004; Bragazza et al. 2006; Wu et al. 2014;) and biodiversity (Berendse et al. 2001; Chapman et al. 2003; Limpens et al. 2011). Ombrotrophic peats can have a range of $\mathrm{N}$ contents; for example in northern peatlands the range is $0.2 \%$ to $3 \%$ (Loisel et al. 2014). Such variation likely has implications for carbon fixation, peat functioning and sensitivity to increased $\mathrm{N}$ inputs.

Peat $\mathrm{N}$ contents depend upon inputs from $\mathrm{N}$ fixation and atmospheric deposition, and losses by burial into the anaerobic catotelm, leaching, erosion and microbial processing including denitrification. Data compiled by Loisel et al. (2014) imply an average long-term (i.e. thousands of years) burial rate of $\mathrm{N}$ in northern peatlands of the order of $0.5 \mathrm{~g} \mathrm{~m}^{-2} \mathrm{a}^{-1}$. Since $\mathrm{N}_{\text {dep }}$ values of this magnitude are a phenomenon of only the last half-century (Vitousek et al., 1997; Fowler et al., 2004), this accumulation is due almost entirely to inputs by $\mathrm{N}$ fixation, which must also account for losses by processes other than burial. Nitrogen fixation rates of the required magnitude, or even greater, have indeed been reported for ombrotrophic bogs (Martin and Holding, 1978; Hemond 1983; Vile et al., 2014).

Whereas $\mathrm{N}$ can be acquired by fixation from the atmosphere, $\mathrm{P}$ cannot, and this may be significant because $\mathrm{P}$ is required for $\mathrm{N}$ fixation both as a constituent of the responsible organisms and through the ATP energy-transferring function (Sprent and Raven 1985; Elser et al. 2007; Augusto et al. 2013; Batterman et al. 2013; Reed et al. 2013; Vitousek et al. 2013). Although in most soils, the supply of P is primarily from mineral weathering, this is not the case for ombrotrophic peat, which by definition receives most or all of its inputs from the atmosphere in rain, dust, biological debris from other ecosystems, and the activities of insects, birds and mammals (Rydin and Jeglum 2013; Tipping et al. 2014). Therefore $P$ acquisition is likely a major determinant of variations amongst peats with respect to nutrition, including $\mathrm{N}$ fixation. Indeed, the role of $\mathrm{P}$ as a limiting factor of biomass growth and functioning in peatlands has been clearly demonstrated (Fritz et al. 2012; Larmola et al. 2013; Hill et al. 2014). Whilst there have been no studies looking specifically at $P$ effects on biological $N$ fixation in peatlands, the findings that $\mathrm{P}$ additions increase both peatland plant $\mathrm{N}$ uptake (Limpens et al. 2004) and microbial $N$ processing (White and Reddy 2000) illustrate the importance of $P$ in peatland $\mathrm{N}$ cycling.

Given the influences of ambient temperature and moisture regimes on biological $\mathrm{N}$ cycling (Rustad et al. 2001; Houlton et al. 2008; Ollivier et al. 2011), it is likely that climate also affects $\mathrm{N}$ acquisition 
91 by peats. Positive effects of temperature on the $\mathrm{N}$ dynamics of peat bogs (Weedon et al. 2012) and 92 on biological $\mathrm{N}$ fixation by bryophytic symbionts (Houlton et al. 2008; Lindo et al. 2013) have been 93 demonstrated. Moisture has also been shown to be important for feathermoss-associated $\mathrm{N}$ fixation 94 (Gundale et al. 2009; Jackson et al. 2011).

95 To obtain a wider picture of the possible controlling effects of $\mathrm{P}$ and climate on the variation of the $\mathrm{N}$ 96 content of ombrotrophic peats, we conducted a meta-analysis of data for a total of 277 sites across 97 boreal, temperate and tropical regions. 


\section{METHODS}

We defined three data sets as follows (Table 1): UK-only, wider global (all data except UK), combined (all data). The data were divided between UK and wider global sites because of the much greater number of UK data (see Results). Values for surface peat total $N$ concentrations $\left(\mathrm{N}_{\mathrm{sp}}\right)$ and surface peat total $\mathrm{P}$ concentrations $\left(\mathrm{P}_{\mathrm{sp}}\right)$ measured simultaneously at the same ombrotrophic peatland sites were collated from both published literature and previously unpublished data (Table S1). The previously unpublished data were for UK sites from the Centre for Ecology and Hydrology (A F Harrison pers. comm.), Scottish Soils Database (Hudson et al. 2012), and for Finnish sites from the University of Helsinki ( $R$ Laiho, pers. comm.). In total our database comprises data from 277 ombrotrophic peatland sites including 215 from the UK, 14 from other temperate localities, 14 from boreal regions and 34 from the tropics (see Table S1 and Figure 1). 'Surface' peat was defined as peat sampled from starting depths of 0-10 cm from the surface down to a maximum of $25 \mathrm{~cm}$ from the surface. The mean sample depth was $15 \mathrm{~cm}$. Analytical methods for measurements of $\mathrm{N}_{\mathrm{sp}}$ and $P_{s p}$ for each data source are summarised in Table S1. All peat samples had a C concentration $\geq 40 \%$, the mean $\mathrm{C}$ concentration across all sites being $51 \%$. We assume that both $\mathrm{N}$ and $\mathrm{P}$ in these organic rich soils are overwhelmingly in organic forms. None of the sites considered have been afforested or fertilised. For the UK, however, some sites may have been subjected to variable intensities of drainage.

Values for mean annual precipitation (MAP, m), mean annual temperature (MAT, ${ }^{\circ} \mathrm{C}$ ), and total annual $\mathrm{N}$ deposition ( $\mathrm{N}_{\text {dep }}, \mathrm{g} \mathrm{m}^{-2} \mathrm{a}^{-1}$ ) were collated for each site (Table $\mathrm{S} 1$ ). For the UK sites, MAP and MAT are 1970-2000 means from the UK Meteorological Office, and $N_{\text {dep }}$ data are 2006-2008 means derived by the CBED model (Smith et al. 2000). For sites not in the UK, MAP and MAT are either values reported in each publication, or 1930-1960 means from the global data set of Cramer and Leemans (2001), with months summed or averaged to give annual values. For all non-UK sites, $N_{\text {dep }}$ data are modelled values for 1993 (Dentener 2006). 
The collated data cover appreciable ranges of $N_{s p}, P_{s p}, M A P, M A T$ and $N_{\text {dep }}$ (Table 1). The values of $N_{s p}$ vary by a factor of 7 and those of $P_{s p}$ by a factor of 19 , while the NP ratio ranges from 6 to 138 . The mapped data (Figure 1) show that the wider global data come from a broad range of locations, although remote peatland localities such as northern Canada and Russia are under-represented. From Table S1 it can be seen that tropical and UK locations have the highest values of $\mathrm{N}_{s p}$, while NP ratios are lowest for non-UK temperate and boreal sites, and highest for tropical sites, with UK sites in between. Values of MAP and MAT were not significantly correlated for the UK sites, but for the wider global set we found a strong positive correlation which can be parameterised as MAP $=0.49$ $e^{0.077 \text { MAT }}\left(r^{2}=0.96, p<0.001\right)$, and for the combined data set the relationship is MAP $=0.93 e^{0.053 \text { MAT }}$ $\left(r^{2}=0.53, p<0.001\right)$. For neither the UK nor the wider global data set was $N_{\text {dep }}$ correlated to MAP or MAT.

Regression analysis of the relationships of $\mathrm{N}_{\mathrm{sp}}$ to individual potential driving variables for the combined data set revealed highly significant $(p<0.001)$ positive correlations with $P_{s p}$ and MAP, and significant $(p<0.01)$ positive correlations with MAT and $\mathrm{N}_{\text {dep }}$ (Figure 2). However, none of the relationships explained very much of the variation in $\mathrm{N}_{s p}\left(r^{2} \leq 0.23\right)$. The NP ratio varied positively and significantly with both MAT $\left(r^{2}=0.10, p<0.001\right)$ and MAP $\left(r^{2}=0.11, p<0.001\right)$.

Because increased $\mathrm{N}_{\text {dep }}$ is a fairly recent phenomenon, and most prevalent in temperate regions, we also conducted a separate analysis of the observations made after 2000 for temperate sites only ( $n=$ 68). This increased the value of $r^{2}$ from 0.03 for the combined dataset $(n=277)$ to 0.07 , but the significance was lower $(p<0.05)$. Furthermore, we found that neither UK $N_{s p}$ nor the UK NP ratio in surface ombrotrophic peat increased with time between 1963 and 2009.

We applied the following multiple regression model to the data;

$$
\log N_{s p}=c 1 \times \log P_{s p}+c 2 \times \log M A P+c 3 \times \log (M A T+10)+c 4 \times \log N_{d e p}+c 5
$$

We used log-transformed data to meet the requirements for a normal distribution of the residuals, and added 10 to the MAT values to make them all positive. Because of the imbalance in the spatial distribution of the data, in particular the large number of UK sites, we conducted separate multiple regression analyses of relationships between $\mathrm{N}_{\mathrm{sp}}$ and the drivers for UK sites only, wider global data, and combined data. The overall picture was the same in each case, with highly significant dependences on $\mathrm{P}_{\mathrm{sp}}$ and MAP and weaker ones on MAT and $\mathrm{N}_{\text {dep }}$ (Table 2, Figure 3). Furthermore, the values of the coefficients $c 1$ and $c 2$ were similar for the three data sets, whereas $c 3$ and $c 4$ were 
157 of the $\mathrm{N}_{\mathrm{sp}}$ variance in the UK, wider global, and combined data sets respectively. The standard errors 158 in $\log \mathrm{N}_{\mathrm{sp}}(0.12,0.09,0.13)$ were less diverse than the $\mathrm{r}^{2}$ values.

159 A simplified model using only $\mathrm{P}_{\mathrm{sp}}$ and MAP explained $29 \%, 84 \%$ and $44 \%$ of the variances in the UK, 160 wider global, and combined data sets respectively, with standard errors of $0.12,0.09$ and 0.13 (Table 161 S2). If MAT was used with $P_{s p}$, the fits were poorer although still highly significant $(p<0.001)$, 162 explaining $27 \%, 76 \%$ and $31 \%$ of the variances, with standard errors of $0.12,0.11$ and 0.15 (Table 163 S3). 
The results show that ombrotrophic peat $\mathrm{N}_{\mathrm{sp}}$ depends strongly upon $\mathrm{P}_{\mathrm{sp}}$ and MAP. The results of the multiple regression analyses are consistent with a multiplicative effect, which can be expressed as;

$$
\mathrm{N}_{\mathrm{sp}}=k \mathrm{P}_{\mathrm{sp}}{ }^{11} \mathrm{MAP}^{c 2}
$$

with values of $k, c 1$ and $c 2$ of 3.9. 0.35 and 0.44 respectively (Table S2). Because $c 1$ and $c 2$ are both less than one, $\mathrm{N}_{\mathrm{sp}}$ is most sensitive to $\mathrm{P}_{\mathrm{sp}}$ and MAP when the two drivers have low values, and the relative response decreases as they get larger (Figure S1). The dependence on $\mathrm{P}_{\mathrm{sp}}$ is consistent with the need for this element in $\mathrm{N}$ fixation (see Introduction), and raises the question as to whether ombrotrophic peats might be P-limited. Indeed P has been found to limit Sphagnum growth at sites receiving high $\mathrm{N}$ deposition (Aerts et al. 1992; Gunnarsson and Rydin 2000; Bragazza et al. 2004) and increased investment in $\mathrm{P}$ acquisition via phosphatase activity has been observed with peatland $\mathrm{N}$ additions (Phuyal et al., 2008).

Both temperature and moisture are likely to affect $\mathrm{N}$ accumulation, either through $\mathrm{N}$ fixation or by affecting other biogeochemical processes in peats (see Introduction). It also seems possible that the MAP effect arises from seasonal variation, with disruption of $\mathrm{N}$ cycling processes occurring during times of moisture deficiency - for example, during periods of low temperature and precipitation in boreal winters and periods of low rainfall in temperate summers. Although significant temperature effects appear when only $P_{s p}$ and MAT are used as explanatory variables (Table S3), stronger relationships are found with MAP as the second explanatory variable (Table S2), and when both MAP and MAT are included in the multiple regression model, the former is selected as the more explanatory (Table 2). Interpretation here is confounded by the correlation between MAP and MAT, especially in the wider global data set. However, with the UK data set this correlation is not seen, and it may be significant that this is the one instance where both MAP and MAT are significant predictors (Table 2). Therefore we cannot rule out a separate dependence on MAT of $\mathrm{N}_{\mathrm{sp}}$, and it may be that our data are insufficient to draw it out. Nonetheless, it is quite clear that climate exerts a strong effect on the $\mathrm{N}$ content of ombrotrophic peats. Furthermore, the positive correlations of peat NP ratio to MAT and MAP suggest that in warmer, wetter regions, proportionally more $\mathrm{N}$ is incorporated into surface peat per unit $\mathrm{P}$ than in colder, drier regions, which suggests a greater efficiency of $\mathrm{P}$ utilisation for $\mathrm{N}$ acquisition where climatic conditions favour biological activity.

Our results show that $N_{s p}$ does not depend strongly on $N_{\text {dep }}$, even when data are selected to make a fairer comparison by considering only samples collected over a constrained time period, or in a restricted climate zone. There are significant positive responses, but the relationships explain little variation in the data. Although there is evidence that current $\mathrm{N}$ deposition influences the $\mathrm{N}$ 
concentration of Sphagnum moss (Bragazza et al. 2005), because elevated $N_{\text {dep }}$ is a recent occurrence, there probably has not been sufficient time for it to affect $\mathrm{N}_{\mathrm{sp}}$ as considered here, most of which has instead accumulated via $\mathrm{N}$ fixation. Furthermore, it is known that, at least in forest ecosystems, $\mathrm{N}_{\text {dep }}$ down-regulates $\mathrm{N}$ fixation (DeLuca et al., 2008), and this will tend to cancel any effects of deposition.

The wider global data set is explained very well by equation (2), but not so well the UK data, in terms of $r^{2}$, and this may partly be a statistical artefact because the wider global data are more evenly spread. The SE values (Tables 2, S2, S3) in predicted $\mathrm{N}_{\mathrm{sp}}$ are not so different among the three data sets considered, although it is still true that the SE values for the UK-only and combined data sets are higher than that for the wider global set. Whilst to our knowledge the sites included in our analysis were all subject to minimal human disturbance, current and past management practices such as drainage, grazing and burning may have affected their nutrient status (Ramschunder et al. 2009; Jauhiainen et al. 2012; Andersen et al. 2013). This is particularly the case for the UK with its long history of upland management for livestock and grouse rearing (JNCC 2011), and site specific variations in land-management practices may therefore have contributed to the weaker correlation between surface peat $\mathrm{N}$ and surface peat $\mathrm{P}$ concentrations and climate for the UK sites. Other factors which might account for the unexplained variance in the data include plant type, the effects of atmospherically-deposited contaminants (sulphur, heavy metals, persistent organic pollutants), and the availability of other nutrients.

The great current interest in the role of peatlands in regional and global carbon cycles has resulted in the publication of major reviews (e.g. Limpens et al. 2008; Lindsay 2010; Yu 2012), and the development of sophisticated models (Frolking et al. 2010; Heinemeyer et al. 2010), but only recently has attention has been focused on the role of nutrients and nutrient stoichiometry in carbon fixation (Wu and Blodau 2013; Wang et al. 2014, 2015). As noted by Vile et al. (2014), ombrotrophic peats are highly efficient at fixing $C$, having net primary production values typically of several hundred $\mathrm{g} \mathrm{m}^{-2} \mathrm{a}^{-1}$ despite their low nutrient status. This is due to the low nutrient contents of their vegetation and high nutrient use efficiency (Small 1972; Wang et al 2014).

However, accumulating peats have to combat the loss of nutrients by burial in the catotelm, and while peatland plants may actively hold nutrients in the top layers of peat bogs (Malmer 1998) perhaps by mycorrhizal uptake (Wang et al. 2014), they still bury a good deal of N (Loisel et al. 2014), which necessitates high rates of $\mathrm{N}$ fixation. Indeed, the $\mathrm{N}$ fixation rates of 1 to $3 \mathrm{gN} \mathrm{m}^{-2} \mathrm{a}^{-1}$ reported for bogs by Martin and Holding (1978), Hemond (1983) and Vile et al. (2014) are comparable to the highest rates estimated for different global ecosystems by Cleveland et al. (1999). Our results 
strongly suggest that a key factor in the ability of peatlands to carry out $\mathrm{N}$ fixation, and thereby $\mathrm{C}$

231 fixation, is $\mathrm{P}$ availability, with important modification by climatic conditions, especially precipitation. It seems especially important to understand how peatlands, especially remote ones, acquire $P$, and how this may have varied over time, given for example Holocene-scale variations in dust transfer (Cockerton et al. 2014) and recent anthropogenic enhancement of this flux (Neff et al. 2008). The incorporation of $\mathrm{N}$ and $\mathrm{P}$ cycling into models of peat growth is a pressing need.

\section{ACKNOWLEDGEMENTS}

We thank Raija Laiho (University of Helsinki) for providing unpublished data. HT, ET, JFB and PAH were funded by the UK Natural Environment Research Council Macronutrient Cycles Programme (LTLS project, Grant no. NE/J011533/1), RCH and AL by the Rural and Environment Science and Analytical Services Division of the Scottish Government. We are grateful to T Moore for his constructive review comments. The outline map in Figure 1 is used with the permission of Presentation Magazine.

247 Table S1 Surface peat $\mathrm{N}$ and $\mathrm{P}$ database

248 Table S2 Multiple regression analysis results $P_{s p}$ and MAP only.

249 Table S3 Multiple regression analysis results $\mathrm{P}_{\mathrm{sp}}$ and MAT only.

250 Figure $\mathrm{S} 1 \quad$ Predicted dependence of $\mathrm{N}_{\mathrm{sp}}$ on $\mathrm{P}_{\mathrm{sp}}$ at different MAP values $\left(\mathrm{m} \mathrm{yr}^{-1}\right)$ 
Aerts R, Wallen B, Malmer N (1992) Growth-limiting nutrients in sphagnum-dominated bogs subject to low and high atmospheric nitrogen supply. J Ecol 80: 131-140

Allan M, Le Roux G, Piotrowska N, Beghin J, Javaux E, Court-Picon M, Mattielli N, Verheyden S, Fagel N (2013) Mid- and late Holocene dust deposition in western Europe: the Misten peat bog (Hautes Fagnes - Belgium). Clim. Past 9: 2285-2298

Andersen R, Chapman SJ, Artz RRE (2013) Microbial communities in natural and disturbed peatlands: A review. Soil Biol Biochem 57: 979-994

Anderson JAR (1983) The tropical peat swamps of western Malesia. In: Ecosystems of the world 4B. Mires: swamp, bog, fen and moor. (ed. Gore AJP) Elsevier, Amsterdam

Augusto L, Delerue F, Gallet-Budynek A, Achat DL (2013) Global assessment of limitation to symbiotic nitrogen fixation by phosphorus availability in terrestrial ecosystems using a meta-analysis approach. Global Biogeochem Cycles, 27: 804-815

Batterman SA, Wurzburger N, Hedin LO (2013) Nitrogen and phosphorus interact to control tropical symbiotic $\mathrm{N}_{2}$ fixation: a test in Inga punctata. J Ecol 101: 1400-1408

Berendse F, Van Breemen N, Rydin H, Buttler A, Heijmans M, Hoosbeek MR, Lee JA, Mitchell E, Saarinen T, Vasander $\mathrm{H}$, Wallen B (2001) Raised atmospheric $\mathrm{CO}_{2}$ levels and increased $\mathrm{N}$ deposition cause shifts in plant species composition and production in Sphagnum bogs. Global Change Biol 7: 591-598

Bragazza L, Gerdol R (1999) Hydrology, groundwater chemistry and peat chemistry in relation to habitat conditions in a mire on the South-eastern Alps of Italy. Plant Ecol 144: 243-256

Bragazza L, Gerdol R (2002) Are nutrient availability and acidity-alkalinity gradients related in Sphagnum-dominated peatlands? J Veg Sci 13: 473-482

Bragazza L, Rydin H, Gerdol R (2005) Multiple gradients in mire vegetation: a comparison of a Swedish and an Italian bog. Plant Ecol 177: 223-236

Bragazza L, Limpens J, Gerdol R, Grosvernier P, Hájek M, Hájek T, Hajkova P, Hansen I, lacumin P, Kutnar L, Rydin H, Tahvanainen $T$ (2005) Nitrogen concentration and $\delta^{15} \mathrm{~N}$ signature of ombrotrophic Sphagnum mosses at different $\mathrm{N}$ deposition levels in Europe. Glob Change Biol 11: $106-114$

Bragazza L, Freeman C, Jones T, Rydin H, Limpens J, Fenner N, Ellis T, Gerdol R, Hajek M, Hajek T, Lacumin P, Kutnar L, Tahvanainen T, Toberman H (2006) Atmospheric nitrogen deposition promotes carbon loss from peat bogs. Proceedings of the National Academy of Sciences of the United States of America 103: 19386-19389. 
Bragazza L, Tahvanainen T, Kutnar L, Rydin H, Limpens J, Hajek M, Grosvernier P, Hajek T, Hajkova P, Hansen I, lacumin P, Gerdol R (2004) Nutritional constraints in ombrotrophic Sphagnum plants under increasing atmospheric nitrogen deposition in Europe. New Phytol 163: 609616

Bridgham SD, Updegraff K, Pastor J (1998) Carbon, nitrogen, and phosphorus mineralization in northern wetlands. Ecology 79: 1545-1561

Chapman S, Buttler A, Francez A, Laggoun-Defarge F, Vasander H, Schloter M, Combe J, Grosvernier P, Harms H, Epron D, Gilbert D, Mitchell E (2003) Exploitation of northern peatlands and biodiversity maintenance: a conflict between economy and ecology. Front Ecol Environment 1: $525-532$

Cheesman, AW, Turner BL, Reddy KR (2012) Soil Phosphorus forms along a strong nutrient gradient in a tropical ombrotrophic wetland. Soil Sci Soc Am J 76: 1496-1506

Clarkson BR, Schipper LA (2004a) Vegetation and peat characteristics of restiad bogs on Chatham Island (Rekohu), New Zealand. New Zeal J Bot 43: 365-365

Clarkson BR, Schipper LA, Lehmann A (2004b) Vegetation and peat characteristics in the development of lowland restiad peat bogs, North Island, New Zealand. Wetlands 24: 133151

Cleveland CC, Townsend AR, Schimel DS, Fisher H, Howarth RW, Hedin LO, Perakis SS, Latty EF, Von Fischer JC, Elseroad A, Wasson MF (1999) Global patterns of terrestrial biological nitrogen $\left(\mathrm{N}_{2}\right)$ fixation in natural ecosystems. Global Biogeochem Cycles 13: 623-645

Cockerton HE, Holmes JA, Street-Perrott FA, Ficken KJ (2014) Holocene dust records from the West African Sahel and their implications for changes in climate and land surface conditions, J Geophys Res Atmos 119: 8684-8694

Cramer WP, Leemans R (2001) Global 30-Year Mean Monthly Climatology, 1930-1960, Version 2.1 (Cramer and Leemans). Data set from Oak Ridge National Laboratory Distributed Active Archive Center, Oak Ridge, Tennessee, USA

Damman AWH (1978) Distribution and movement of elements in ombrotrophic peat bogs. Oikos 30: 480-495

DeLuca TH, Zackrisson O, Gundale MJ, Nilsson M-C (2008) Ecosystem feedbacks and nitrogen fixation in boreal forests. Science 320: 1181

Dentener FJ (2006) Global Maps of Atmospheric Nitrogen Deposition, 1860, 1993, and 2050. Data set from Oak Ridge National Laboratory Distributed Active Archive Center, Oak Ridge, Tennessee, USA 
Elser JJ, Bracken MES, Cleland EE, Gruner DS, Harpole WS, Hillebrand H, Ngai JT, Seabloom EW, Shurin JB, Smith JE (2007) Global analysis of nitrogen and phosphorus limitation of primary producers in freshwater, marine and terrestrial ecosystems. Ecol Lett 10: 1135-1142

Emmett BA, Reynolds B, Chamberlain PM, Rowe E, Spurgeon D, Brittain SA, Frogbrook Z, Hughes S, Lawlor AJ, Poskitt J, Potter E, Robinson DA, Scott A, Wood C, Woods C (2010) Countryside Survey: Soils Report from 2007. Technical Report No. 9/07 NERC/Centre for Ecology and Hydrology (CEH Project Number: C03259)

Fritz C, van Dijk G, Smolders AJP, Pancotto VA, Elzenga TJTM, Roelofs JGM, Grootjans AP (2012) Nutrient additions in pristine Patagonian Sphagnum bog vegetation: can phosphorus addition alleviate (the effects of) increased nitrogen loads. Plant Biol 14: 491-499

Frolking S, Roulet NT, Tuittila E, Bubier JL, Quillet A, Talbot J, Richard PJH (2010) A new model of Holocene peatland net primary production, decomposition, water balance, and peat accumulation Earth Syst Dynam 1: 1-21

Fowler D, O'Donoghue M, Muller J, Smith R, Dragosits U, Skiba U, Sutton M, Brimblecombe P (2004) A chronology of nitrogen deposition in the UK between 1900 and 2000. Wat Air Soil Pollut: Focus 4: 9-23

Gundale MJ, Gustafsson H, Nilsson M-C (2009) The sensitivity of nitrogen fixation by a feathermosscyanobacteria association to litter and moisture variability in young and old boreal forests. Can J For Res 39: 2542-2549

Gunnarsson U, Rydin H (2000) Nitrogen fertilization reduces Sphagnum production in bog communities. New Phytol 147: 527-537

Hayati AA, Proctor MCF (1991) Limiting nutrrients in acid-mire vegetation - peat and plant analyses and experiments on plant responses to added nutrients. J Ecol 79: 75-95

Hemond HF (1983) The Nitrogen Budget of Thoreau's Bog. Ecology. 64: 99-109

Heinemeyer A, Croft S, Garnett MH, Gloor E, Holden J, Lomas MR, Ineson P (2010) The MILLENNIA peat cohort model: predicting past, present and future soil carbon budgets and fluxes under changing climates in peatlands. Clim Res 45:207-226

Hill BH, Elonen CM, Jicha TM, Kolka RK, Lehto LLP, Sebestyen SD, Seifert-Monson LR (2014) Ecoenzymatic stoichiometry and microbial processing of organic matter in northern bogs and fens reveals a common P-limitation between peatland types. Biogeochem 120: 203-224 Houlton BZ, Wang YP, Vitousek P, Field CB (2008) A unifying framework for dinitrogen fixation in the terrestrial biosphere. Nature 454: 327-331 
Jackson BG, Martin P, Nilsson M-C, Wardle DA (2011) Response of feather moss associated $\mathrm{N}_{2}$ fixation and litter decomposition to variations in simulated rainfall intensity and frequency. Oikos 120: 570-581

Joint Nature Conservation Committee. (2011). Towards an assessment of the state of UK Peatlands. JNCC, Peterborough.

Keller JK, Bauers AK, Bridgham SD, Kellogg LE, Iversen CM (2006) Nutrient control of microbial carbon cycling along an ombrotrophic-minerotrophic peatland gradient. J Geophys Res 111: G03006

Larmola T, Bubier JL, Kobyljanec C, Basiliko N, Juutinen S, Humphreys E, Preston M, Moore TR (2013) Vegetation feedbacks of nutrient addition lead to a weaker carbon sink in an ombrotrophic bog. Global Change Biology 19: 3729-3739

Limpens J, Berendse F, Klees H (2004) How phosphorus availability affects the impact of nitrogen deposition on Sphagnum and vascular plants in bogs. Ecosystems 7: 793-804

Limpens J, Granath G, Gunnarsson U, Aerts R, Bayley S, Bragazza L, Bubier J, Buttler A, van den Berg LL, Francez AJ, Gerdol R, Grosvernier P, Heijmans MMPD, Hoosbeek MR, Hotes S, Ilomets M, Leith I, Mitchell EAD, Moore T, Nilsson MB, Nordbakken JF, Rochefort L, Rydin H, Sheppard L, Thormann M, Wiedermann MM, Williams BL, Xu B (2011) Climatic modifiers of the response to nitrogen deposition in peat-forming Sphagnum mosses: a meta-analysis. New Phytol 191: 496-507.

Limpens J, Berendse F, Blodau C, Canadell JG, Freeman C, Holden J, Roulet N, Rydin H, SchaepmanStrub G (2008) Peatlands and the carbon cycle: from local processes to global implications a synthesis Biogeosci 5: 1475-1491

Lindo Z, Nilsson M-C, Gundale MJ (2013) Bryophyte-cyanobacteria associations as regulators of the northern latitude carbon balance in response to global change. Global Change Biol 19: 20222035

Lindsay R (2010) Peatbogs and carbon: a critical synthesis to inform policy development in oceanic peat bog conservation and restoration in the context of climate change. Report to RSPB Scotland.

Loisel J, Yu Z, Beilman DW, Camill P, Alm J, Amesbury MJ, Anderson D, Andersson S, Bochicchio C, Barber K, Belyea LR, Bunbury J, Chambers FM, Charman DJ, De Vleeschouwer F, FialkiewiczKoziel B, Finkelstein SA, Galka M, Garneau M, Hammarlund D, Hinchcliffe W, Holmquist J, Hughes P, Jones MC, Klein ES, Kokfelt U, Korhola A, Kuhry P, Lamarre A, Lamentowicz M, Large D, Lavoie M, MacDonald G, Magnan G, Makila M, Mallon G, Mathijssen P, Mauquoy D, McCarroll J, Moore TR, Nichols J, O'Reilly B, Oksanen P, Packalen M, Peteet D, Richard PJH, 
Robinson S, Ronkainen T, Rundgren M, Sannel ABK, Tarnocai C, Thom T, Tuittila E-S, Turetsky M, Valiranta M, van der Linden M, van Geel B, van Bellen S, Vitt D, Zhao Y, Zhou W (2014) A database and synthesis of northern peatland soil properties and Holocene carbon and nitrogen accumulation. Holocene 24,: 1028-1042

Malmer N (1998) Patterns in the Growth and the Accumulation of Inorganic Constituents in the Sphagnum Coveron Ombrotrophic Bogs in Scandinavia. Oikos 53: 105-120

Martin NJ, Holding AJ (1978) Nutrient Availability and Other Factors Limiting Microbial Activity in the Blanket Peat. In Production Ecology of British Moors and Montane Grasslands (eds Heal OW, Perkins DF), Springer, Berlin, pp. 113-135.

Minkkinen K, Vasander H, Jauhiainen S, Karsisto M, Laine J (1999) Post-drainage changes in vegetation composition and carbon balance in Lakkasuo mire, Central Finland. Plant Soil 207: $107-120$

Moore TR, Trofymow JA, Siltanen M, Kozak LM (2008) Litter decomposition and nitrogen and phosphorus dynamics in peatlands and uplands over 12 years in central Canada. Oecologia 157: $317-325$

Neff JC, Ballantyne AP, Farmer GL, Mahowald NM, Conroy JL, Landry CC, Overpeck JT, Painter TH, Lawrence CR, Reynolds RL (2008) Increasing eolian dust deposition in the western United States linked to human activity. Nature Geosci 1: 189-195

Ollivier J, Toewe S, Bannert A, Hai B, Kastl E-M, Meyer A, Su MX, Kleineidam K, Schloter M (2011) Nitrogen turnover in soil and global change. FEMS Microbiology Ecology 78: 3-16

Page SE, Rieley JO, Shotyk OW, Weiss D (1999) Interdependence of peat and vegetation in a tropical peat swamp forest. Phil Trans R Soc Lond Ser B-Biol Sci 354: 1885-1897

Pajunen H (1994) Physical and chemical properties of peat in Rwanda, Central Africa. Bull Geol Soc Finl 394: 1-61

Pakarinen P, Gorham E (1984) Mineral element composition of Sphagnum fuscum peats collected from Minnesota, Mannitoba and Ontario. In: Proceedings of the International Peat Symposium, October 1983 (ed. Spigarelli S) Bemidji State University, Bemidji, pp. 471-479

Phuyal M, Artz RRE, Sheppard L, Leith ID, Johnson D (2008) Long-term nitrogen deposition increases phosphorus limitation of bryophytes in an ombrotrophic bog. Plant Ecology 196: 111-121

Ramchunder SJ, Brown LE, Holden J (2009) Environmental effects of drainage, drain-blocking and prescribed vegetation burning in UK upland peatlands. Progress in Physical Geography 33: 49-79

Reed SC, Cleveland CC, Townsend AR (2013) Relationships among phosphorus, molybdenum and free-living nitrogen fixation in tropical rain forests: results from observational and experimental analyses. Biogeochemistry 114: 135-147 
Richardson CJ, Tilton DL, Kadlec JA, Chamie JPM, Wentz WA (1978) Nutrient dynamics of northern wetland ecosystems. In: Freshwater wetlands: ecological processes and management potential. (eds. Good RE, Whigham DF, Simpson RL). Academic Press, New York, pp. 217-241

Rustad LE, Campbell JL, Marion GM, Norby RJ, Mitchell MJ, Hartley AE, Cornelissen JHC, Gurevitch J (2001) A meta-analysis of the response of soil respiration, net nitrogen mineralization, and aboveground plant growth to experimental ecosystem warming. Oecologia 126: 543-562

Rydin H, Jeglum JK (2013) The Biology of Peatlands, Second Edition. Oxford University Press

Small E (1972) Photosynthetic rates in relation to nitrogen recycling as an adaptation to nutrient deficiency in peat bog plants. Can J Bot 50: 2227-2233

Smith RI, Fowler D, Sutton MA, Flechard C, Coyle M (2000). Regional estimation of pollutant gas dry deposition in the UK: model description, sensitivity analyses and outputs. Atmos Environ 34: 3757-3777

Sprent JI, Raven JA (1985) Evolution of nitrogen-fixing symbioses. Proc Roy Soc Edinburgh B Biol Sci 85: $215-237$

Tipping EW, Smith EJ, Lawlor AJ, Lofts S, Simon BM, Vincent CD, Stidson R, Rey-Castro C, Longworth H, Reynolds B, Hughes S, Brittain SA (2003) Hydrochemistry of Organic Soils. Final CEH Report WI/C01259/2

Tipping E, Benham S, Boyle JF, Crow P, Davies J, Fischer U, Guyatt H, Helliwell R, Jackson-Blake L, Lawlor AJ, Monteith DT, Rowe EC, Toberman H (2014) Atmospheric deposition of phosphorus to land and freshwater. Environ Sci-Proc Impacts 16: 1608-1617

Turetsky MR, Wieder RK, Williams CJ, Vitt DH (2000) Organic matter accumulation, peat chemistry, and permafrost melting in peatlands of boreal Alberta. Ecosci 7: 379-392

Turunen J, Roulet NT, Moore TR, Richard PJH (2004) Nitrogen deposition and increased carbon accumulation in ombrotrophic peatlands in eastern Canada. Global Biogeochem Cycles 18: GB3002, doi:10.1029/2003GB002154

Vile M, Wieder RK, Živković T, Scott K, Vitt D, Hartsock J, losue C, Quinn J, Petix M, Fillingim H, Popma JA, Dynarski K, Jackman T, Albright C, Wykoff D (2014) $\mathrm{N}_{2}$-fixation by methanotrophs sustains carbon and nitrogen accumulation in pristine peatlands. Biogeochem 121: 317-328

Vitousek PM, Aber JD, Howarth RW, Likens GE, Matson PA, Schindler DW, Schlesinger WH, Tilman D (1997) Human alteration of the global nitrogen cycle: sources and consequences. Ecol Appl 7:737-750

Vitousek PM, Menge DNL, Reed SC, Cleveland CC (2013) Biological nitrogen fixation: rates, patterns and ecological controls in terrestrial ecosystems. Phil Trans Roy Soc London B Biol Sci 368: 20130119-20130119 
Wang M, Moore TR, Talbot J, Richard PJH (2014) The cascade of C:N:P stoichiometry in an ombrotrophic peatland: from plants to peat. Environ. Res. Lett. 9: 024003 (7pp)

Wang M, Moore TR, Talbot J, Riley JL (2015) The stoichiometry of carbon and nutrients in peat formation. Glob Biogeochem Cycles 29: doi:10.1002/2014GB005000

Weedon JT, Kowalchuk GA, Aerts R, van Hal J, van Logtestijn R, Tas N, Roling WFM, van Bodegom PM (2012) Summer warming accelerates sub-arctic peatland nitrogen cycling without changing enzyme pools or microbial community structure. Global Change Biol 18: 138-150

White JR, Reddy KR (2000) Influence of phosphorus loading on organic nitrogen mineralization of everglades soils. Soil Sci Soc Am J 64: 1525-1534

Wu Y, Blodau C (2013) PEATBOG: a biogeochemical model for analyzing coupled carbon and nitrogen dynamics in northern peatlands. Geosci Model Dev: 6, 1173-1207

Wu Y, Blodau C, Moore TR, Bubier JL, Juutinen S, Larmola T (2014) Effects of experimental nitrogen deposition on peatland carbon pools and fluxes: a modeling analysis. Biogeosci Disc 11: 10271-10321 
471 Table 1. Summary of data. See Table S1 for details.

\begin{tabular}{|c|c|c|c|c|c|c|c|c|}
\hline Data source & $\mathrm{n}$ & $\begin{array}{c}\text { time } \\
\text { period }\end{array}$ & $\begin{array}{c}\mathrm{N}_{\mathrm{sp}} \\
\% \\
\end{array}$ & $\begin{array}{c}\mathrm{P}_{\mathrm{sp}} \\
\% \\
\end{array}$ & $N: P$ & $\begin{array}{c}\text { MAP } \\
\mathrm{m}\end{array}$ & $\begin{array}{c}\text { MAT } \\
{ }^{\circ} \mathrm{C} \\
\end{array}$ & $\begin{array}{c}\mathrm{N}_{\text {dep }} \\
\mathrm{g} \mathrm{m}^{-2} \mathrm{a}^{-1} \\
\end{array}$ \\
\hline UK $^{1}$ & 215 & $1963-2009$ & $0.5-3.6$ & $0.01-0.19$ & $11-138$ & $0.8-2.8$ & $2.7-10.8$ & $0.4-3.0$ \\
\hline Wider global' & 62 & $1971-2012$ & $0.5-2.9$ & $0.02-0.15$ & $6-85$ & $0.4-4.0$ & $-3.8-26.4$ & $0.0-1.9$ \\
\hline Combined & 277 & $1963-2012$ & $0.5-3.6$ & $0.01-0.19$ & $6-138$ & $0.4-4.0$ & $-3.8-26.4$ & $0.0-3.0$ \\
\hline
\end{tabular}

472

$473{ }^{1}$ From: Scottish Soils Database; Emmett et al. 2007; Tipping et al. 2003; AF Harrison pers commun;

474 Hayati and Proctor, 1991

4752 From: Minkkinen et al. 1999; Moore et al. 2008; Bragazza et al. 2005; Turetsky et al. 2000;

476 Pakarinen and Gorham 1984; Richardson et al. 1978; Damman 1978; R Laiho pers commun; Keller et

477 al. 2006; Bragazza and Gerdol 1999; Bragazza and Gerdol 2002; Clarkson et al. 2004a; Clarkson et al.

478 2004b; Bridgham et al. 1998; Hill et al. 2014; Cheesman et al. 2012; Page et al. 1999; Anderson 1983;

479 Pajunen 1994

480

481

482 
483 Table 2. Multiple regression analysis results; dependence of $\mathrm{N}_{s p}$ on $\mathrm{P}_{\mathrm{sp}}, \mathrm{MAP}$, (MAT+10) and $\mathrm{N}_{\text {dep }}$ for 484 log-transformed data; coefficients c1-c5 refer to equation (1)

\begin{tabular}{|c|c|c|c|c|c|c|c|c|c|}
\hline & $\begin{array}{r}\text { Variable } \\
\text { Coefficient }\end{array}$ & $\begin{array}{l}P_{s p} \\
c 1\end{array}$ & $\begin{array}{l}\text { MAP } \\
\text { c2 }\end{array}$ & $\begin{array}{c}\text { MAT+10 } \\
\text { c3 }\end{array}$ & $\begin{array}{l}\text { Ndep } \\
\text { c4 }\end{array}$ & $\begin{array}{c}\text { const } \\
\text { c5 }\end{array}$ & $r^{2}$ & SE & $\mathrm{p}$ \\
\hline \multirow[t]{3}{*}{ UK } & Value & 0.30 & 0.35 & 0.89 & -0.09 & -0.52 & 0.36 & 0.12 & $1.6 \times 10^{-19}$ \\
\hline & SE & 0.04 & 0.07 & 0.21 & 0.05 & 0.27 & & & \\
\hline & $p$ & $1.2 \times 10^{-10}$ & $2.9 \times 10^{-7}$ & $4.4 \times 10^{-5}$ & 0.057 & 0.055 & & & \\
\hline \multirow[t]{3}{*}{ Wider global } & Value & 0.43 & 0.56 & 0.03 & -0.02 & 0.51 & 0.84 & 0.09 & $8.2 \times 10^{-22}$ \\
\hline & SE & 0.07 & 0.11 & 0.17 & 0.03 & 0.23 & & & \\
\hline & $p$ & $8.2 \times 10^{-8}$ & $2.2 \times 10^{-6}$ & 0.87 & 0.51 & 0.032 & & & \\
\hline \multirow[t]{3}{*}{ Combined } & Value & 0.33 & 0.37 & 0.11 & 0.09 & 0.44 & 0.47 & 0.13 & $6.2 \times 10^{-37}$ \\
\hline & SE & 0.04 & 0.06 & 0.10 & 0.02 & 0.12 & & & \\
\hline & $p$ & $2.0 \times 10^{-14}$ & $4.2 \times 10^{-9}$ & 0.30 & $6.0 \times 10^{-5}$ & $3.1 \times 10^{-4}$ & & & \\
\hline
\end{tabular}

485

486

487

488 
490

491 Figure 1. Map showing ombrotrophic peat sites. The numbers insider the symbols are the numbers 492 of data for each country or region.

493 Figure 2. Relationships between surface peat $\% \mathrm{~N}\left(\mathrm{~N}_{\mathrm{sp}}\right)$ and surface peat \%P $\left(\mathrm{P}_{\mathrm{sp}}\right)$, mean annual 494 precipitation (MAP), mean annual temperature (MAT) and atmospheric $\mathrm{N}$ deposition ( $\left.\mathrm{N}_{\text {dep }}\right)$ for the 495 combined dataset. Trend lines and $r^{2}$ are for linear regression $(n=277)$; the regressions are all 496 significant, \%P and MAP both $p<0.001$, MAT and $N_{\text {dep }}$ both $p<0.01$.

497 Figure 3. Observed $N_{s p} v s$. values predicted from linear multiple regressions with $P_{s p}$, MAT, MAP and $498 \quad N_{\text {dep }}$ as independent variables. The 1:1 lines are shown. Numbers of data points are given in Table 1. 


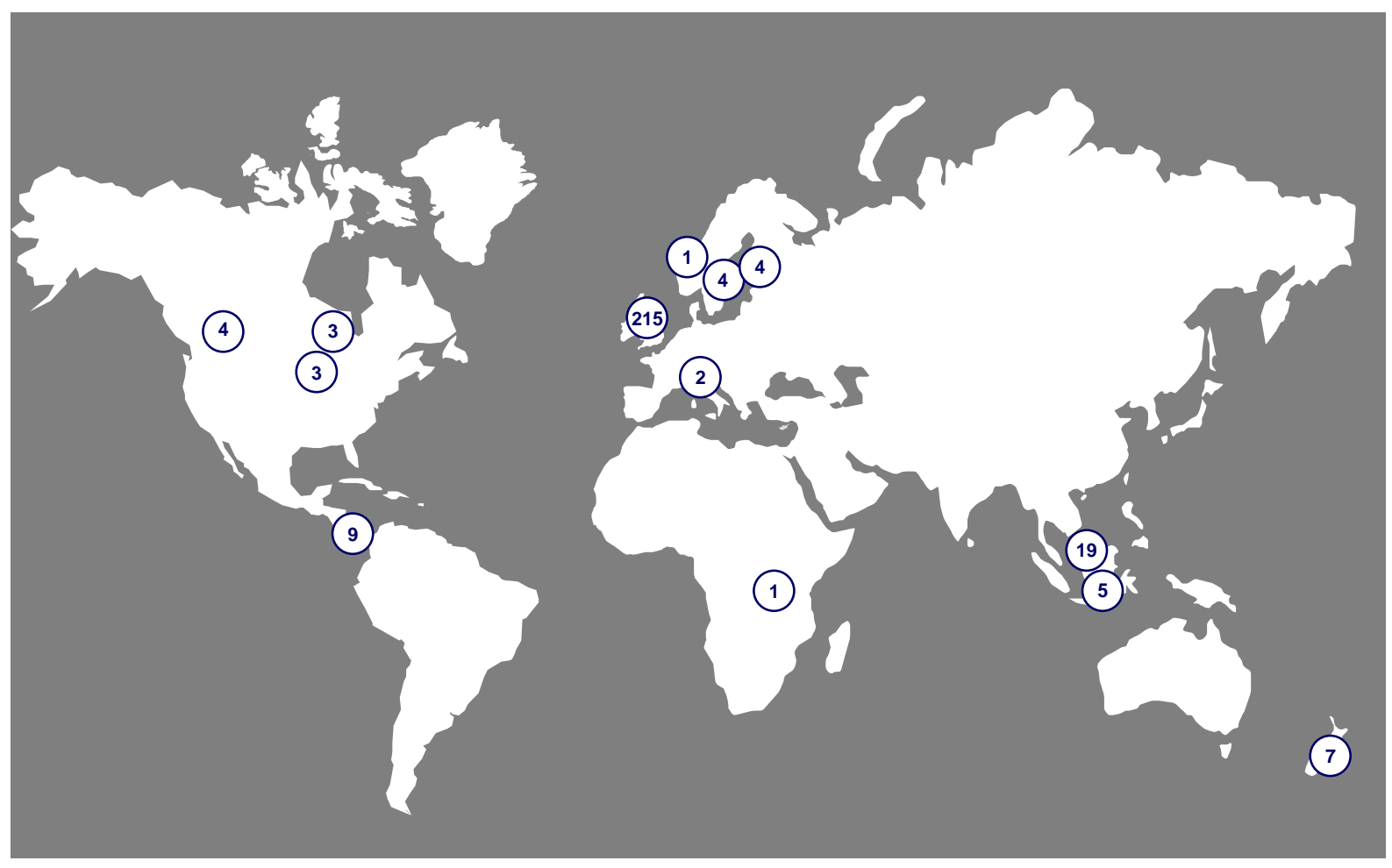

501

502 Figure 1 

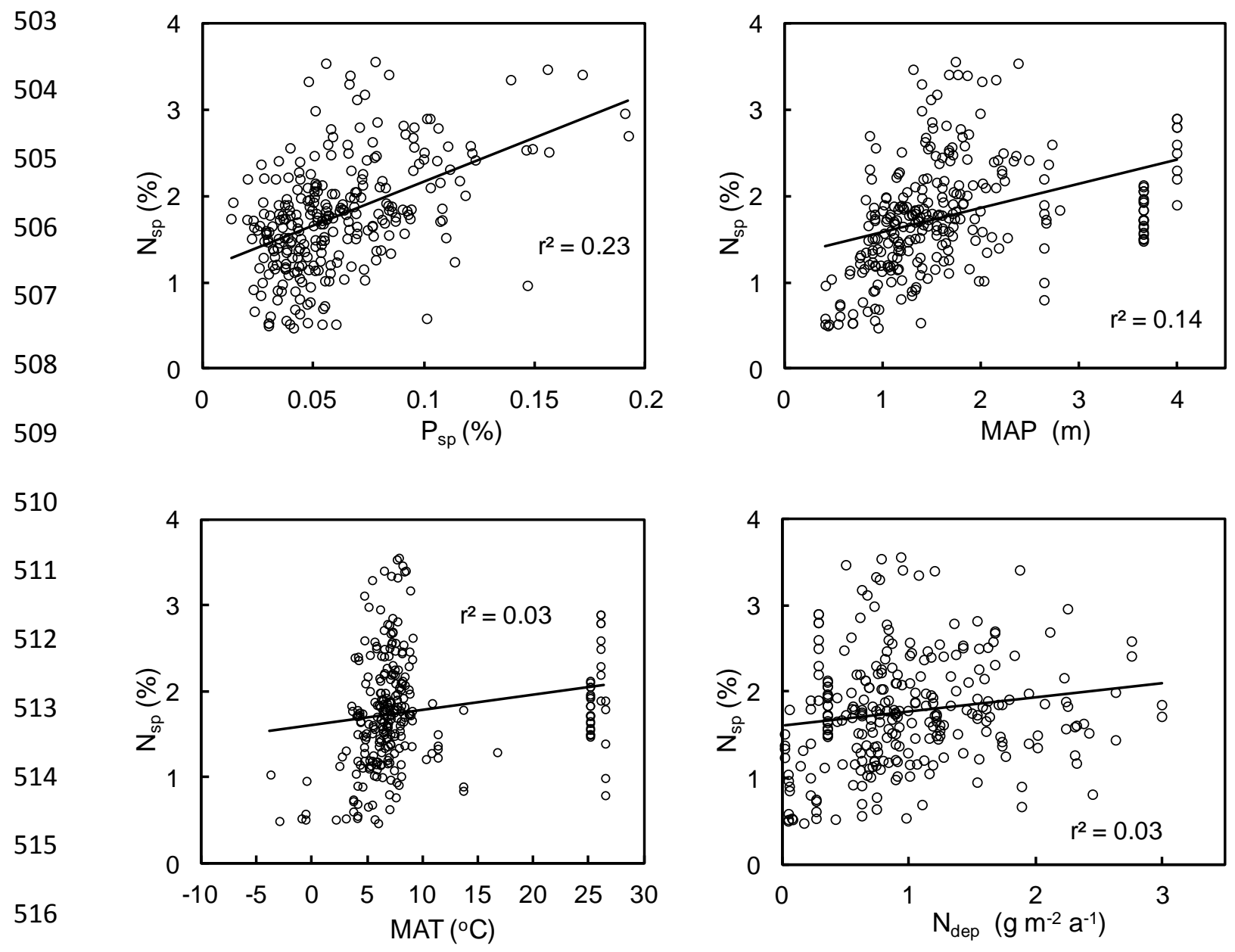

517

518 Figure 2

519 

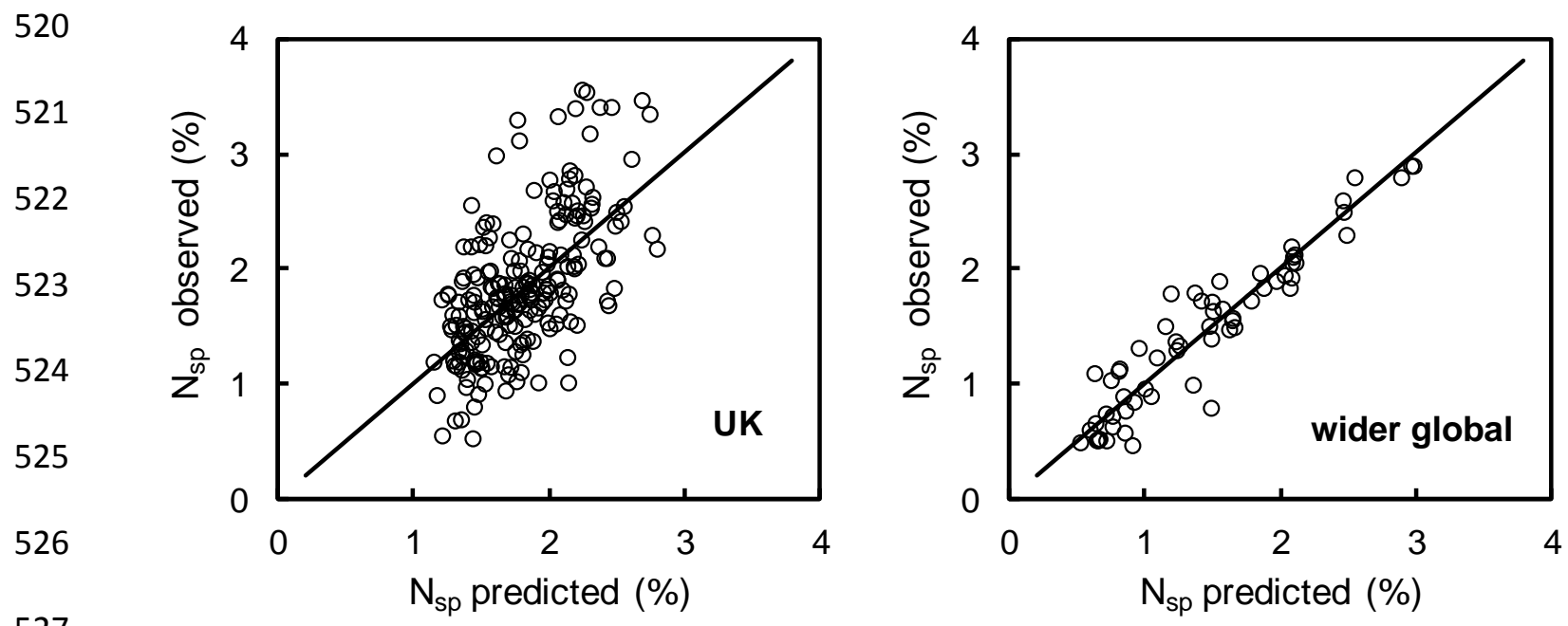

528

529

530

531

532

533

534

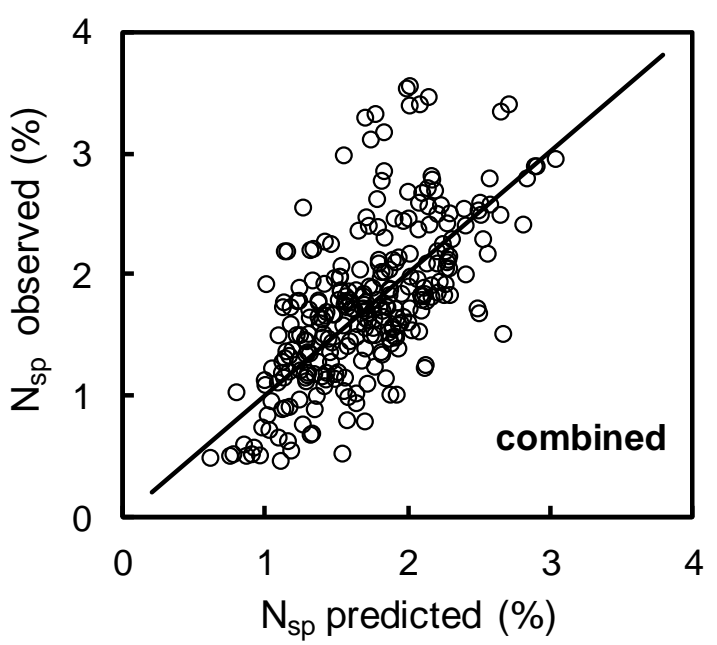

$535 \quad$ Figure 3

536

537 